\title{
Smysl má bránit jakékoli vzdělávací obsahy
}

\author{
(ReakCE Na disKusní PŘísPĚVeK ZuZany DanišKovÉ: MÁ vÝZNAM \\ BRÁNIŤ „NEPRODUKTÍVNE“ VZDELÁVACIE OBSAHY V DNEŠNÝCH ČASOCH?)
}

\section{Petr Urbánek}

Explicitně a hlouběji se tématem kurikula nezabývám. Tematika príspěvku Zuzany Daniškové v tomto čísle mě však zaujala, nebot je pro akt výchovy a vzdělávání zásadní a rozhodně nekončí na hranici didaktické kategorie učiva. $V$ důsledcích vede $\mathrm{v}$ procesu výuky bezprostředně $\mathrm{k}$ žákovi a $\mathrm{k}$ učiteli, zasahuje však také samotný smysl vzdělávání. Přesto, že se přirozeně nedomnívám, že by školní děti měly být nadměrně a encyklopedicky zahlcovány učivem, troufám si hned $\mathrm{v}$ úvodu reagovat na vyslovenou otázku $\mathrm{Zu}$ zany Daniškové v titulku její časopisecké diskuse: Nejenže má zcela klíčový význam bránit, ale je i životně důležité ubránit tzv. neproduktivní vzdělávací obsahy současného školního vzdělávání. Nejedná se přitom „pouze“ o vzdělávací obsahy a riziko tlaku na jejich vyprazdňování, které zasluhují vnímavost a ochranu. Problém má v souvislostech podstatně širší rozměr.

Kaščák a Pupala (2011, s. 26-29) vnímají tragiku práce školy v šíri a prorostlosti celkové „neoliberální mentality“ do sféry výchovy a vzdělávání všech stupňů. Domnívám se proto, že „obranu“ kromě obsahů vzdělávání vyžaduje veškerá podstata výchovy a smysl vzdělávání, které jsou stále silněji vystavovány neoliberálním praktikám. Hájit hodnoty výchovy a vzdělávání by měla především akademická fronta. Znalostním potenciálem a expertním přesvědčením mohou akademici nejlépe obsáhnout složitost doby $\mathrm{v}$ její hloubce a predikcích, komplexně v souvislostech, $s$ odborným vhledem, $\mathrm{v}$ adekvátním výchovném kontextu, $\mathrm{v}$ relevantní struktuře. A při hledání cesty $\mathrm{k}$ pravdě $\mathrm{i} \mathrm{k}$ dítěti (snad) stále ještě i nezaujatě, bez břemene vnějších závazků a tlaků nebo utilitárních zájmů. Odlišné hlasy, ač jsou dnes slyšet daleko silněji a $\mathrm{z}$ více stran, však primárně podstatu a smysl vzdělávání nehájí. Vycházejí povětšinou z účelovosti, vlastního prospěchu, komerčních a politických zájmů, či prostě jen z nekritického nadšení, amatérské naivity a v módním zajetí fetišizace dítěte.

Na své uvedené odpovědi, že je nutné bránit školní vzdělávací obsahy jako dynamický, historicky logický celek s kultivační funkcí, ze kterého nelze účelově a nahodile preparovat zdánlivě nepotřebné, musím trvat. Nastolená otázka obrany obsahů školního vzdělávání totiž současně otevírá širší problém soudobé krize školy, a také 
krize vyprazdňující se společnosti. A to nejen obsahově, ale $\mathrm{v}$ důsledcích i ideově a morálně. $\mathrm{Na}$ diskusní príspěvek Zuzany Daniškové budu proto reagovat nejspís poněkud netypicky: nikoli polemicky nebo v rozporu $s$ jejím textem, nikoli kontradiskusně. $S$ uvedenými myšlenkami, argumenty a interpretací se ztotožňuji a několika postřehy si dovolím její stanovisko podpořit a rozšíritit.

Již samotné slovní spojení „neproduktivni vzdělávací obsahy", které autorka $\mathrm{v}$ textu použila ve zřejmé nadsázce, považuji v komplikovanosti současného světa a ve výchovné náročnosti přibližit jeho nepřehlednou realitu dalším generacím za nepatřičné až absurdní a rigorózně nepřijatelné. Kdo je vůbec schopen a povolán odlišit „produktivní" (tedy ty zaručeně "potřebnéc) vzdělávací obsahy od těch neužitečných, zbytečných a neprospěšných? Obsah je ve výchově určován cílem, nikoli ekonomizovanou "produktivitou“ nebo „(ne)potřebností". A problém postmoderní společnosti tkví právě $\mathrm{v}$ neurčitosti a nejasnosti cílů. Formulace tohoto druhu mi proto svou prakticistní arogancí a zjednodušující dogmatickou samožrejmostí připomínají údernické slogany z minulých dob, nad nimiž se dnes sice leckdo už jen pousměje, avšak současně je připraven je v jakési inovované verzi znovu konstruovat, používat a $\mathrm{v}$ pochybném zájmu i prosazovat.

V českém základním školství lze nalézt skrytější i flagrantní př́klady, kdy bylo skoncováno s nějakým „nepotřebným“ učivem, aby se po určité době ukázalo, že pro komplexní kultivaci žáka v kurikulu přece jen chybí. $\mathrm{V}$ nedávné minulosti to byl na vy̌šsím stupni základního vzdělávání vyučovací obsah hned celého předmětu pracovního vyučování, který se zdál být $\mathrm{v}$ počítačové době překonaný, zastaralý, obsahem neužitečný, nejspíše i málo atraktivní. Tedy zcela jistě též chápán jako „neproduktivní“. Obrat v náhledu na redukci polytechnického učiva ale náhle způsobilo zjištění o nedostatečné manuální zručnosti absolventů základních škol a zejména jejich tragicky nízký zájem o profesní profilaci směrem $\mathrm{k}$ řemeslu a $\mathrm{k}$ technickým oborům. (Příčinou takových zjištění přirozeně nemohla být jen absence kvalitní polytechnické výchovy ve školách.) Nyní se zase navrací učivo pracovního vyučování obtížně do škol zpět, když už mnohde chybí kvapně rušené dílny a pro výuku kvalifikovaní učitelé.

Tragičnost lehkovážného zacházení se školními obsahy jakéhokoli druhu se projevuje také v destrukci školy jako instituce. Pakliže dnes škola lacině „nadbíhác nesystémovým tlakům (nejen) rodičů, aby tak uspokojila různorodé individuální představy „klientely“ o správné náplni a fungování vzdělávací instituce, zbavuje tím učitele profesní autonomie a školu institucionální identity i smyslu, kterému má sloužit.

Pro ilustraci prakticistní pošetilosti, s jakou jsme ochotni nezabývat se ve vzdělávání plnohodnotnými obsahy a selektovat jen ty právě potřebné, si dovolím uvést jednu analogii, resp. alegorii. Vystihuje sice v obecnější a materiálnější rovině, ale svou tragikou v témže principu, tematiku „nepotřebnosti“" učiva. Nepromyšlené vyzobávání „neproduktivních“ 
vzdělávacích obsahů totiž připomíná neblahou historickou skutečnost, kdy právě inventáře (tedy obsahy) kulturních klenotů mnoha českých památek, a tím i jejich vlastní smysl, byly jako celek negovány ideologií účelovosti a (s)měly též sloužit jen ryze pragmatickému využití. Barokní kř́idla řady venkovských zámků se přeměnila na kanceláre lesních či zemědělských závodů nebo byty jejich zaměstnanců. Francouzské parky zase na parkoviště i vrakoviště traktorů a kombajnů. Alibisticky mohly v té době zaznívat obdobně „logické“ otázky, analogické těm, které slýcháme i v oblasti školního učiva: Jak k produktivitě přispívá kazetový strop či nemoderní kachlová kamna? K čemu je $\mathrm{v}$ zámeckém parku fontána s barokní skulpturou, zvláště zabírá-li zbytečně tolik místa? Celek a smysl byl degradován na užitnou hodnotu obytné plochy a cenu zdiva. Z praktického pohledu té doby šlo o prospěšné využití neproduktivních artefaktů, a dělo se tak jistě také $\mathrm{v}$ zájmu vyšší produkce či výkonu. Přirozeně, že s těmito proměnami je ovšem též generována tomu odpovídající redukovaná kultura a myšlení. Dodnes se na mnoha místech tyto barbarské skutky nepodařilo přes značné finanční toky napravit, a leckteré již ani napravit nelze. Nepřipomínám však ,jen“ zničenou matérii kulturních hodnot. $S$ ní ruku v ruce byla vykořeněna tradice, kontinuita, historická pamět a kontexty, které dnes citelně chybí. Destruovány byly hodnoty a kultivovanost lidí, kteří v takto omezeném prostředí v celých dalších generacích existovali a privykali mu. Také $\mathrm{v}$ realitě školního vzdělávání jsou směrem $\mathrm{k}$ učivu stále častěji artiku- lovány otázky o užitečnosti jednotlivých elementů bez ohledu na pochopení celku. Vzdělávací obsahy jsou jen se značnými riziky dělitelným celkem. $S$ odstraněním, tedy omezením obsahových celků o „neproduktivní" prvky, se pak může vytrácet podstata, smysl, kontinuita a souvislosti.

Vzdělávání a jeho obsahy nemohou být omezeny na pouhý výčet právě potřebných znalostí či dovedností, které společnost aktuálně vyžaduje a které mají mnohdy již na úrovni základního vzdělávání charakteristiky obsahů profesní př́pravy. Jsou až úsměvné představy, jak např. zařazení finanční gramotnosti ve výuce malých dětí nadobro skoncuje v celých dalších generacích $s$ dlužníky a tragédiemi exekucí. Jako by problém souvisel primárně $s$ početními operacemi a nikoli se zodpovědností. Škola přece dokáže svou důsledností každodenních prozaických školních požadavků na žáka (tak často kritizovaných) v něm zcela přirozeně budovat odpovědnost, k sobě i ke společnosti.

Zuzana Danišková svou diskusi vede ve struktuře čtyř vymezených oblastí, $\mathrm{k}$ nimž postmoderní tlak na vzdělávací obsahy mírí, a ve svých důsledcích je zpochybňuje, relativizuje nebo i neguje jejich podstatu a smysl: obsahy pro otevreni náhledu; pro proménu; pro volný čas; a obsahy pro morálku. Přestože text Daniškové pokrývá čtyřmi subtématy dostatečně široký diskusní prostor obsahů školního vzdělávání, a i přesto, že autorka $s$ adekvátní oporou naplňuje cíl diskuse a zdařile tak „rehabilituje netriviálnost a významnost formálního školního kurikula“, dovolím si text přeci jen ještě tematicky 
doplnit a dále rozšíritit o jednu specifickou obsahovou oblast.

Diskusi proto pootočím poněkud jiným, zpravidla obecně méně debatovaným směrem. Pokrývá také téma vzdělávacích obsahů, avšak v rovině učitelského vzdělávání. $V$ učivu (budoucích) učitelů lze totiž také nalézt riziko zneužití, resp. snahu eliminovat klíčovou složku obsahu až do silně pragmatických poloh. Na tuto skutečnost upozorňují Kaščák a Pupala (2011), když uvádějí mezi pěti segmenty vzdělávací sféry, ve kterých si „neoliberalismus zjevně prorazil svoji cestu a které dobře ilustrují logiku sociálních změn vedenou sledovaným hodnotovým diktátem“ (s. 6), nepřiměřený obrat $\mathrm{k}$ praxi také $\mathrm{v}$ učitelské př́pravě. Reálným dokladem toho mohou být $\mathrm{u}$ nás $\mathrm{v}$ poslední době etablované některé, jistě dobře míněné, inicitativy prakticky zaměřených „inovativních učitelských kvalifikačních programü“, resp. „unikátních výcvikư “ a „tréninkü “ zaměřených na rozvoj osobnosti učitele, na schopnost vytvářet a udržovat vztahy. Zpravidla méně ovšem bývá akcentována znalost obsahu nebo didaktická práce $s$ učivem jako zcela klíčová učitelská aktvita. Učitelské vzdělávání se jistě nemůže odehrávat zcela mimo praktickou zkušenost studenta se školským terénem a každá dobře vedená praktická aktivita je pro adepta učitelství př́nosná. Uvedené pragmaticky zaměřené iniciativy, pakliže by byly systémově nabízeny všem absolventům univerzitního učitelského studia při nástupu do školské praxe, bych považoval za velmi užitečné. Obávám se ovšem, že uvedený jednoroční praktický „trénink“ či „výcvik“, jak je de- klarován, nepřímo neguje smysl důkladné akademické prýpravy a mohl by být i u nás brzy decizí zneužit a chápán jako rovnoprávná alternativa $\mathrm{k}$ vysokoškolskému učitelskému vzdělávání. Tuto obavu potvrzuje poměrně brutální text, který deklaruje některé snahy v zahraničí prosadit prakticistní př́istupy do učitelského vzdělávání: „,... vláda musí trvat na tom, aby se co nejvíce otevřel ,trh` škol a praktická činnost měla přednost před vysokoškolskou př́pravou. Tržní realita je nejlepším vzdělavatelem. Ideálně by se měl vytvořit volný trh, kdy školy budou mít možnost vybrat, kohokoli budou chtít - se vzděláním nebo bez něj..." (Furlong et al., 2000, s. 10). Citace zřejmě nikoli náhodou připomíná svou formou i obsahem doby minulé, tentokrát však z ideologické dílny „tržních svazákü“. Neměli bychom se však jen proto domnívat, že jsou méně nebezpečné.

I v mnohých českých a zahraničních odborných pedeutologických textech prrinejmenším implicitně zaznívá, že právě praktický nácvik je tím pravým lékem na neduhy učitelského vzdělávání a že právě on vede ke kýžené profesionalizaci (budoucích) učitelů. Domnívám se, že řešení, které musí nabízet fakulty, leží spíše na opačném pólu, tedy na kvalitní akademické př́ípravě. Zásadní koncepční i realizační otázkou učitelského vzdělávání je, jaká je vyváženost obsahových složek praxe a teoretické přípravy, a především způsob, jakým se $s$ praktickým nácvikem zachází ve smyslu integrace obou těchto složek a jejich reflexe. Zvykově vžitá realita, dlouhodobě živená absencí systematizovaného postgraduálního vzdělávání učitelů, že 
zodpovědnost za praktickou př́ípravu (budoucího) učitele má ležet na učitelských fakultách, je scestná, nesmyslná.

$\mathrm{Na}$ jiném místě mimo tento text, a s odkazem na Bertranda (1998), jsem se pokusil „rehabilitovat“ akademický koncept učitelského vzdělávání (Urbánek, 2016, s. 47). Jeho atributem je právě silná zaměřenost na kultivačně obsahovou složku vzdělávání s vysokým potenciálem formálního rozvoje a odhalováním interpretačních schémat. Také $\mathrm{v}$ učitelském vzdělávání se setkáváme $s$ tím, že je obsahová složka degradována a redukována o „zbytečné, nepotřebné“ učivo budoucích učitelů, s představou o vyšších efektech praktického nácviku a pragmaticky orientovaných kompetenčních modelů. Kritiku akademického modelu učitelského vzdělávání vnímají Kaščák a Pupala jako paradoxní (2011, s. 26), nebot' tak, jak jsem na jiných místech již uvedl, zcela přehlíží dlouholeté úsilí a ideový zápas za vysokoškolskou př́pravu učitelů (Urbánek, 2016, s. 52). Pakliže jsme se ze zcela logických důvodů a v souladu s kontinuální linií přes preparandy a učitelské ústavy vydali na cestu vysokoškolské, ba univerzitní př́pravy učitelů, je $s$ tímto rozhodnutím spojen i požadavek kultivovat studenty a budoucí učitele akademickými obsahy. Již výše, na př́kladu vyloupených, vybydlených a zdevastovaných kulturních památek, byly rizika a důsledky pošetilých zásahů a tragického zacházení s materiálně duchovními obsahy zmíněny. Nápadnou analogii i se všemi důsledky vidím ve vyprazdňování obsahů vzdělávání. I proto má smysl bránit jakékoli vzdělávací obsahy.

\section{Literatura}

Bertrand, Y. (1998). Soudobé teorie vzdělávání. Praha: Portál.

Danišková, Z. (2017). Má význam bránit „neproduktívne“ vzdelávacie obsahy v dnešných časoch? Pedagogika, 67(3), 295-305.

Furlong, J., Barton, L., Miles, S., \& Whitty, G. (2000). Teacher education in transition: Reforming teacher professionalism? Milton Keynes: Open University Press.

Kašćák, O., \& Pupala, B. (2011). Neoliberalizmus vo vzdelávaní: pät obrazov kritických analýz. Pedagogická orientace, 21(1), 5-34.

Urbánek, P. (2016). Akademický či kompetenční koncept vzdělávání učitelů. Nutná bipolarita? In M. Strouhal (Ed.), Učit se být učitelem. Kvybraným problémům učitelského vzdèlávání (s. 44-69). Praha: Karolinum.

Doc. PaedDr. Petr Urbánek, Dr.,

Technická univerzita v liberci, Fakulta prírodovèdnè-humanistni a pedagogická, katedra pedagogiky a psychologie;

e-mail:petr.urbanek@tul.cz 